Andrzej Margasiński, PhD, https:/ / orcid.org/0000-0002-2902-3973

Faculty of Psychology

Department of Social Science

Jan Dtugosz University

in Czesstochowa

Bogna Białecka, MA, https:/ / orcid.org/0000-0002-0626-2947

Foundation for Health Education and Psychotherapy

\title{
Developmental Regularities and the Issue of Adopting Homosexual Orientation by Adolescents - a Review of Research and Opinions
}

\author{
Prawidłowości rozwojowe a problematyka przyjmowania orientacji \\ homoseksualnej przez młodzież - przegląd badań i opinii ${ }^{1}$ \\ https:// doi.org/10.34766/fetr.v47i3.697
}

\begin{abstract}
The article responds to practical dillemas of parents, psychologists or educators who come across teenagers declaring their homosexual orientation. In this overview, the authors discuss primary developmental factors and they point out the dynamic specific of adolescence, comprising also a psychosexual growth. Current research review shows that sexual orientation has a developmental and often fluent character, mostly in a heterosexual direction, and that a research on homosexuality leads to the conclusion, that it's etiology is multifactoral, with predominance of environmental over the genetic factors. For these reasons, early declarations of homosexual orientation uttered by teenagers rather should not be supported.
\end{abstract}

Keywords: sexual orientation, sexuality, homosexuality, developmental factors, adolescence

Abstrakt: Artykuł podejmuje kwestie praktycznych dylematów rodziców, psychologów czy wychowawców spotykających się z nastolatkami deklarującymi swoją homoseksualną orientację. W przeglądowym tekście autorzy omawiają podstawowe czynniki rozwojowe i dynamiczną specyfikę okresu dorastania, obejmującą także rozwój psychoseksualny. Przegląd współczesnych badań wskazuje, że orientacja seksualna ma charakter rozwojowy i nierzadko płynny, z reguły w kierunku heteroseksualnym, a badania nad przyczynami homoseksualizmu doprowadzają do konkluzji, iż jego etiologia jest wieloczynnikowa, z przewagą oddziaływań środowiskowych nad genetycznymi. $Z$ tych powodów wczesnych deklaracji o orientacji homoseksualnej głoszonych przez nastolatków raczej nie powinno się wspierać.

Słowa kluczowe: orientacja seksualna, seksualność, homoseksualizm, czynniki rozwojowe, dorastanie

\section{Introduction}

This piece of work is devoted to the difficult and usually controversial issue of homosexual orientation in adolescents. This is a research area undertaken by few authors,

\footnotetext{
${ }^{1}$ Polska wersja: https://stowarzyszeniefidesetratio.pl/Presentations0/2021-3-Marg.pdf
} 
usually avoided by Polish psychologists. It is a kind of blank spot. The issues of sexual orientation, in particular homosexual orientation, is usually connected with a natural conflict between various scientific disciplines. For developmental psychology or psychopathology, the basis is a descriptive perspective, whilst for areas such as educational psychology, pedagogy of upbringing, or sexology it is not sufficient, after all, these are the disciplines of science which are to develop specific educational recommendations addressed to young people. There is no doubt that from the point of view of researchers dealing with the difficult issues of sexual orientation, it is easier to remain on the descriptive level, focused on explaining phenomena and various dependencies. However, the education/ counselling/preventive dimensions in relation to adolescents cannot be avoided. In this sense, the following piece of work is also the area of psychology of education and pedagogy and may have applications for sexology. Parents, psychologists, or tutors who work with adolescents may encounter a situation when they hear declarations or doubts about from adolescents their sexual orientation. We dealt with such situations both in our academic work and in the practice of working with adolescents and parents. Questions arise, what should be the reaction of people accompanying adolescents in their puberty process? Should declarations made by adolescents, such as "I am a lesbian" or"I think I am a gay", be supported or, on the contrary, stopped. In this piece of work, we will touch both levels, descriptive as well as educational and advisory. The first part presents an overview of contemporary findings concerning factors of psycho-sexual development, mechanisms of developing personality and sexual orientation, and the regularities of psycho-sexual development in adolescence. The second part consists of an overview of the opinions of various authors concerning declarations of homosexual orientation made by adolescents. We will also present our conclusions in this regard.

The article is composed of several thematic parts. In the first part, the commonly known developmental conditions and regularities of adolescence will be outlined as the necessary background to describe the issue of sexual orientation. The second part is devoted to describing the mechanisms of shaping sexual orientation, including the emergence of homosexual orientation. The third part includes a review of research on the issue of constancy/variability of sexual orientation. In the summary, dilemmas of the psychologistteenager relationship will be discussed, also with regard to the specificity of the psychotherapeutic relationship.

\section{Developmental background and dynamics of changes}

Reflections on the shaping of sexual orientation cannot be separated from the general developmental background. Below, mainly for readers who are not more familiar with psychology, we will cite the findings commonly accepted in developmental psychology 
which refer to developmental factors and the specific nature of changes in adolescence as an indispensable plane for describing the regularities related to the formation of sexual orientation.

For many decades, there have been fierce disputes about what influences the development of a person's personality and identity to a greater extent - whether biological endowment or the influence of the environment in which an individual lives. These disputes are called "nature or upbringing", "heredity or environment", "genes or culture", where nature is understood as the influence of widely understood biological factors (genes, hormones, neuroanatomical structures), and where upbringing means the environment. From today's perspective, these disputes seem to be ahistorical. It is difficult to find researchers who would support only one of the factors. The vast majority of today's researchers of the genetics of behaviour, individual differences, temperament, or personality recognise development as the resultant of the interaction between genes and environment (Oniszczenko \& Dragan, 2008; Pinker, 2012; Plomin et al., 2001). The mutual influence of genetic predispositions and environmental interactions, as defined by Pervin and John (2002), is always a dynamic interaction that can give different results. First of all, the same experiences can have a different impact on people who have different genetic predispositions. Secondly, individuals with different genetic predispositions may cause different reactions of environment (parents react differently to an excitable child, and differently to a calm and sensitive child), and thirdly, environments are created by people of various integrity (an extrovert looks for a different environment than an introvert). As the authors conclude:

"From some point in the course of development, it becomes impossible to define to what extent a person is a "recipient" of environmental influences, and to what extent a person is their "creator" (Pervin \& John, 2002, p. 345).

One determinant cannot be considered apart from the other:

"Genes and the environment cannot be considered as separate factors. They are rather different aspects of a single system. (...) Genes can influence the environment, and the environment can regulate genes activity" (Kosslyn \& Rosenberg, 2006, s. 144).

Understanding personality determinants, temperamental features, and finally, psychological gender and sexual orientation cannot take place in any other way than through the analysis of interactions between biological determinants (genes, hormones) and the environment. Any attempts to simplify these analyses to one or the other factor appears today as unjustified reductionism. This does not mean, however, that a mechanical interpretation should be adopted as binding, with the same influence on the development of both factors; everything indicates that they differ depending on what features we are looking at. As noted by Pervin and John: 
"Genetic factors are generally more important for characteristics such as intelligence and temperament, while for values, ideals, and beliefs, they are less important" (Pervin \& John, 2002, p. 9).

Adolescence generally covers the period from 10/12 to 20/23 years old and is divided into two sub-periods: early adolescence (range 10-16 years old) and late adolescence (17-20/23 years old) (Oleszkowicz \& Senejko, 2016). It is the time of the most turbulent changes, covering practically all spheres of an individual's functioning. During adolescence, dynamic hormonal changes occur as a result of transitioning through puberty, e.g., as compared to childhood, the level of secretion of sex hormones (testosterone in boys, oestrogen and progesterone in girls) increases 20 times in boys and 6 times in girls (Wolański, 2012). Research shows that there are intense changes in the brain which matures and develops rapidly. The density of the grey matter decreases, some synapses are lost, whilst others develop. This may be accompanied by an increased susceptibility to negative environmental influences and increased sensitivity to environmental stresses (Dahl, 2004; Strauch, 2004). The development of formal thinking, characterised by the ability to conceptual and abstract thinking, synthesis and analysis skills, and the ability to take into account many variables, is linked to the late stage of adolescence in Piaget's (2012) concept of the development of intelligence. According to Bryant and Coleman (1995), before the age of 16 , the threshold of formal thinking is exceeded by a smaller part of the population. In terms of emotional development, adolescence is characterised by frequent states of emotional ambivalence (Rosenblum \& Lewis, 2004), the prevalence of negative feelings over positive ones (Larson \& Richards, 1994), and frequent states of adolescent depression (Modrzejewska \& Bomba, 2009). There are numerous changes in self-esteem, and the sense of self-esteem and identity evolves. According to the widely accepted concept by Erikson (2004), building an identity is one of the main challenges of adolescence. Marcia (1966), distinguished four types of identity, which differ in the levels of exploration and involvement, treated as development criteria: diffuse (diffusive) identity, mirror identity (assumed, taken over), deferred (moratorium) identity, and achieved (mature) identity (Czyżowska, 2005; Miluska, 1996). Diffuse identity is perceived as the least advanced in terms of development, whilst the most advanced in terms of development is achieved identity, which may occur in adolescents in late adolescence, same as moratorium identity (Musiał, 2007). Moral development is related to the development of identity. According to the classic concept of development of Kohlberg's moral reasoning (1984), it is subject to certain developmental regularities, and it is shaped differently in individual developmental periods. The main feature in the development of morality is the direction from heteronomy to moral autonomy. Only after the age of 16, an individual can reach the post-conventional phase, i.e., based on their own, well thought out, and adopted moral principles. 
The above review of various spheres of human development shows that adolescence is characterised by dynamics and numerous changes, which seems to be its main feature. The concept of developmental stability is not associated with the period of adolescence - both at the level of physical, emotional, moral, and social development. The same regularities apply to the sphere of sexual development.

\section{Development of sexuality and sexual orientation}

With a very large conceptual diversity in the field of personality theories, it seems that at the level of generalisations there is a certain consensus among researchers: personality is generally defined as a complex pattern of psychological features such as feelings, thoughts, attitudes, which are manifested almost automatically in every sphere of psychological behaviour of a person (Millon et al., 2013; Pervin \& John, 2002). On the other hand, sexual orientation is usually understood as a lasting, emotional and sexual attraction to people of the same sex. Questions arise about the mutual dependence between the personality, and sexual orientation, whether sexual orientation is part of personality, or whether it should be treated as an autonomous dimension of a human being "next to" personality. This is an important question. If we treat sexual orientation autonomously, then it is justified to look for specific factors influencing its formation. However, if we consider orientation as part of personality, then reflections on personality development also include the development of sexual orientation. It seems that the concept of personality is a broader term. It includes sexual orientation and identity. These issues are not considered very broadly by researchers, the exceptions include the model of Seligman et al. (2017), in which the authors proposed the division of erotic life into several layers, each of which is based on a lower layer. The undoubted advantage of this model is the ordering of concepts and indicating boundaries between what is norm and pathology. 5 levels were distinguished: gender identity (basic layer, the awareness of being a woman or a man), sexual orientation - heterosexual, homosexual and bisexual (if an individual does not accept their fantasies and homosexual behaviours, the state is referred to as egodystonic homosexuality (incompatible with the ego), which is distinguished as a mental disorder in the International Classification of Mental Diseases and Disorders ICD-10 (kept by WHO, still in force in Poland), sexual preferences (interests) (related to an object, situations, body parts, objects causing sexual arousal), gender role (the way an individual socially marks their masculinity or femininity), and sexual realisation (the degree of adequacy of behaviour with the appropriate person and in the appropriate erotic situation). The distinguished terms are further used in the context of Seligman's model. All these layers make up a specific pattern and constitute a component of a human personality. Therefore, reflections on the shaping of gender identity and sexual orientation are, in a broader perspective, considerations about factors that contribute to 
human development. To conclude, it does not seem that there are serious reasons to consider psycho-sexual development as a less complicated process than personality development, or as a process dependent on one gene.

Human sexual orientation is the result of biological and psychological sex. Its formation is a long process, beginning at the genetic configuration, then the course of the foetal stage, when at about the third month in boys it is possible to distinguish primary sexual features in the form of testes, through reaching biological sexual maturity, to sexual activity and reproduction. Between the ages of 2 and 3, a sense of gender identity evolves, children acquire the ability to assign themselves to a specific gender. Children gain a sense of gender stability at the age of 6-7, they also begin to use stereotypical beliefs about men and women, they prefer playing in gender-separate groups. As shown by studies by Alexander, Wilcox, and Woods (2009), in the last years of preschool children spend only $9 \%$ of their time playing with representatives of the opposite sex. Such segregation persists in younger school grades and gender separation generally lasts until the beginning of puberty, when interest in the opposite sex, usually of a heterosexual nature, develops (Eliot, 2011). Achieving biological maturity and reproductive ability does not end the process of shaping psychosexual identity (gender role in Seligman's concept), understood as statements "I am a heterosexual woman" or "I am a homosexual man". After all, the processes of developing psycho-sexual and social maturity take place simultaneously. These three dimensions cannot be separated in the context of the discussion on the sense of psycho-sexual identity and individual maturity.

Mayer and McHugh (2016, p. 7) in a meta-analysis of contemporary research on sexuality, make a summary of the influence of individual development factors, claiming that: "Recognition of sexual orientation as an innate, purely biological quality, the assumption that "People are born this way" is not supported by scientific evidence."

Such a position seems to prevail in the world of modern science, which was admitted, amongst others, by the American Psychological Association:

"There is no consensus among scientists as to the exact reasons why a particular person develops a heterosexual, bisexual or homosexual orientation. While many researchers have examined the possible role of genetic, hormonal, developmental, social, and cultural factors, none of the research findings allow the conclusion that sexual orientation is determined by any particular factor or factors. Many believe that both nature and upbringing play a complex role" (American Psychological Association, 2018). In recent years, there has been a gradual evolution in the position of the American Psychological Association. In official brochures from previous years $(2008,2009)$, as well as in earlier publications, the American Association strongly opposed the possibility of effective sexual reorientation from homosexual to heterosexual, both through natural change and during reorientation therapy (also referred to as reparative or conversion). In the APA Handbook of 
Sexuality and Psychology of 2014, edited by Tolman and Diamond (a committed lesbian), we find a number of chapters in which sexual orientation is treated as fluid (Bockting, 2014; Diamond, 2014; Kleinplatz \& Diamond, 2014; Rosario \& Schrimshaw, 2014). There is also a shift away from the suggestions of exclusively biological conditioning of homosexuality ("born this way"), which were dominant in previous years, in favour of the interactive theory. In fact, similar conclusions were reached by the authors of a recent research published in Science, which analysed nearly half a million genomes (Ganna i in., 2019). From a wide group of Polish psychologists declaring their affirmative approach to homosexuality (see: Iniewicz, Mijas, \& Grabski, 2012), in the last publication by Grunt-Mejer and Iniewicz (2020, s. 29) they present a similar opinion:

"It is now assumed that sexual orientation, understood primarily as a relatively permanent romantic and sexual attraction towards persons of a given gender, can be shaped by many influences: from genetic and hormonal to social and psychological, none of which has a strictly determining role or explains most of the variance".

Research on identical twins provides significant arguments that the nature of sexual orientation is not inborn. These twins have identical genes and essentially the same hormonal conditions during pregnancy. In research on monozygotic twins (MZ), the influence of a biological factor is considered significant when there are relationships at the level of $75 \%$ or more, relationships at the level of $25 \%$ are considered weak, and the level of $50 \%$ as medium. If sexual orientation was solely genetically determined, then MZ twins should "always" or "almost always" have the same sexual orientation. However, they have no such. Whitehead (2011) analysed the 8 largest contemporary research on MZ twins. The results of this research showed 20-22\% agreement of homosexual orientation in men and 18$37 \%$ in women in monozygotic twins - it can be seen especially in the case of women that we are dealing with large statistical deviations. After taking into account possible variances, it was estimated that the homosexual orientation concordance in MZ twins was $11 \%$ in men and 14\% in women (Paszewski, 2016; Whitehead \& Whitehead, 2018). To compare - when identical twins were examined for the same weight and height at puberty, the agreement was found at $91-97 \%$. In other words, weight and height are mainly biologically determined (Silventoinen et al., 2008), whilst sexual orientation does not show such determinism. It is worth noting that these results show not only the lack of the "homosexual gene" but also that sexual orientation cannot be treated as the sole result of prenatal hormonal influences.

Since sexual orientation is not innate, the homosexual orientation is not inborn. There is no single universally accepted theory among researchers explaining the causes of homosexuality. It is generally pointed out that homosexuality is a combination of many factors, such as:

- biological, e.g., effects of genes, effects of hormones before birth;

- social, e.g., relationships with parents, siblings, peers; 
- cultural, e.g., customs in a given epoch.

Diamond and Rosky (2016, p. 365) write:

"One fact about sexual orientation is almost universally shared by scientists: it does not have a single cause. Rather complex biological and non-biological causes interact with one another and give shape to adult expressions of homosexuality, the set of factors varying from person to person and between genders".

Brodziak and Kłopotowski (2013, p. 264) express themselves in the same spirit:

"The attempts to explain the causes of homosexuality through the interaction of a single causative agent prove inconclusive."

The authors refer to the existence of a fairly wide stream of correlation research, which compiles samples of the heterosexual and homosexual populations and looks for biological differences between them. When such differences are found, researchers sometimes suggest biological determinants of homosexuality. Two such publications became famous in the 1990s. The translation of the formation of homosexuality in terms of changes within one gene (Hamer et al., 1993) was unsuccessful, these studies were not confirmed in other centres, and their author explained that he was "misunderstood" (Hamer \& Copeland, 2007). Similarly, the research by Le Vay (1991), which suggested there was a nucleus of the hypothalamus called INAH3, differentiating between homosexuals and heterosexuals, has not been positively verified. As part of such searches, Lalumiere et al. (2000) showed that homosexuals were more often left-handed; There have been reports of differences between homosexuals and heterosexuals in the ratio of index to ring finger length (Manning et al., 1998), penis size (Bogaert \& Hershberger, 1999), daily activity (Hall \& Kimura, 1995; Rahman \& Silber, 2000). Whitehead and Whitehead (2018, p. 183-184), summarising this research trend, enumerate 18 factors related to biological determinants differentiating the studied groups of homosexual orientation from heterosexual: artistic predispositions, autoimmune thyroid disorders in the mother, fluctuation asymmetry (including asymmetry of facial features), atypical biological sex, hermaphroditism (in a small number of cases), congenital disability, left-handedness, novelty-seeking, obesity (in women), having older brothers (in men), physical impairment, polycystic ovary syndrome, specific features of temperament ("tomboy" type in women, "female" men), pregnancy during adolescence (possible hormonal influences), physical features unusual for women (in women), problems with eye-hand coordination, $\mathrm{X}$ chromosome inactivation (in mothers).

In turn, with regard to the correlation between homosexual orientation and environmental conditions, Whitehead and Whitehead (2018, p. 184-185) distinguished 46 such factors, three times more than biological ones, including alienation from the father in early childhood, overprotective mother (towards boys), a mother who needs and expects a lot (from boys), an emotionally unavailable mother (for girls), parents who have not been able to direct identification with their gender, no "fighting" games in boys, no identification 
with gender, aversion to team sports (boys), teasing by colleagues due to poor eye-hand coordination, sexual abuse or rape, social phobia or extreme shyness, loss of a parent due to death or divorce.

It must be remembered that in science, finding a correlation does not automatically mean cause-effect relationships, which can be extremely complex and multi-faceted. Although such dependencies may occur, they may very well turn out to be a random coincidence.

To sum up: for contemporary researchers, the prevailing view seems to be that homosexuality is a product of complex relationships between social, cultural, and biological factors, but a greater role is played by the influence of environmental factors, and the influence of biological factors is considered indirect and rather weak (Bailey, Miller, \& Willerman, 1993; Bearman \& Brückner, 2002; Garnets, 2002; Paszewski, 2016; Peplau \& Garnets, 2000; Savin-Williams \& Ream, 2007; Whitehead \& Whitehead, 2018). The individuality of the individual's reactions and the importance of cultural differences are emphasised, such an approach is called multivariate or interactive theory.

\section{Dynamic of sexual development}

According to Kernberg (1998), during adolescence, we can talk about sexual disintegration of adolescents, characterised by a gap between showing emotions (tenderness, love, care) and excitement and desire. Young boys are characterised by immaturity, being unstructured, and being unrestrained. Immaturity consists in willingly taking up sexual and pornographic topics, comparing oneself with peers, exposing sexual organs, bragging about sexual experiences, and "gains". The disorder manifests itself in the excessive and inadequate attribution of sexual content and meanings to other people and objects, the lack of clear rules, the lack of clear sexual preferences, and even the lack of clear gender orientation. Unrestrainedness consists in the lack of control of drives, experiencing numerous states of sexual arousal, which may be accompanied by frequent masturbation. Control is expressed in trying to hide them from adults. In the case of girls, the developing sexuality is manifested primarily by the desire for emotional ties and the need for closeness. Sexual disintegration in girls is often expressed through demonstrative denial and the elimination of sexuality. Another way is to approach a person of the same sex, usually older, more mature, attractive. Behind this is the desire to be understood, cared for, and longing for a romantic feelings, devoid of sexual desire (Beisert, 2012).

Many contemporary research show fluidity and changes in sexual feelings during adolescence. Kinnish (2005) conducted a longitudinal study of 420 men and 342 women of heterosexual, homosexual, and bisexual identity, asking respondents to specify their preferences every five years, starting at the age of 16 . It turned out that one or more identity 
changes occurred in 3\% of heterosexual women and men, in the homosexual group changes occurred in $39 \%$ of gays and $64 \%$ of lesbians (a statistically significant difference between the sexes), in the bisexual group in $66 \%$ of men and $77 \%$ of women. Dimensions analyses of sexual fantasies, romantic attraction, and sexual behaviour showed significant differences between the genders in the homosexual group, with lesbians reporting significantly greater variability in all three dimensions. Savin-Williams and Ream (2007) conducted a longitudinal study of a large sample of over 10,000 adolescents, measuring their sexual orientation at 16 , 17 , and 22 years of age. In the group of 16-year-olds, heterosexual feelings prevailed - $79.85 \%$ of the respondents (boys 77.4\%, girls 91.1\%); the next modality was the lack of strong targeting - 13.95\% (boys 15.5\%, girls 12.4\%), then bisexual feelings - 5.1\% (boys 6.3\%, girls $4.3 \%$ ) and homosexual feelings $0.95 \%$ (boys $0.9 \%$, girls $1.0 \%$ ). At the age of 22 , in the same group of respondents, the percentage of people with heterosexual orientation increased to $87.2 \%$ (boys $91.1 \%$, girls $83.3 \%$ ), the number of undecided people decreased to $3.75 \%$ (boys $3.8 \%$, girls $3.7 \%$ ), the percentage of people declaring bisexual feelings increased to $8.3 \%$ (boys $4.3 \%$, girls $12.3 \%$ ), the percentage with a homosexual orientation was $0.8 \%$ (boys $1 \%$, girls 0 , $6 \%$ ). Sexual feelings in men are more stable than in women, but it also fluctuates. Although sexual tendencies are fluid in adolescence, most changes are made towards heterosexuality. As the authors analyse, a 16-year-old who judges himself to be non-heterosexual is 25 times more likely to be heterosexual at 17 than a heterosexual 16-year-old who as a 17-year-old will become non-heterosexual. Research by Ott et al. (2011) showed that although a large group of 12-year-olds experience uncertainty as to whether they are heterosexual, at the age of 23, the vast majority of this group is already convinced of their heterosexuality. The advantage of these studies is their initiation in the age group of 12-year-olds, i.e., at the beginning of puberty (girls) or in the pre-pubertal period (boys), and an impressive research sample of 13,840 adolescents. It turned out that in the youngest surveyed teenagers, uncertainty (unsure) about their own orientation prevails, with age these indicators decrease, and heterosexual feelings increase. The same relationship - variability of non-heterosexual feelings towards heterosexuality and greater stability of heterosexual feelings was demonstrated in research carried out in New Zealand (Dickson et al., 2013) and in earlier research by Remafedi et al. (1998). Diamond (2000) demonstrated the fluidity of feelings, behaviours and a sense of sexual identity in women. Bancroft (2019), a long-term director of the Kinsey Institute, admits that there is a body of evidence that sexual orientation is not always established early and remains the same.

According to Polish research by Izdebski (2006), 3.1\% of women and 1.8\% of men revealed that they used to feel homosexual attraction, but do not feel it now. In a later publication, we find that $2 \%$ of respondents feel homosexual attraction, $4 \%$ felt it only in the past (Izdebski, 2012, p. 760). 
To sum up, based on Kinnish et al. (Kinnish i in., 2005, p. 173-174), it can be stated that:

"The belief that sexual orientation is innate and immutable has been challenged from many theoretical perspectives, such as the theory of social stigma, developmental psychology, the theory of social constructivism, and evolutionary psychology (Baumeister, 2000; D'Augelli, 1994; Diamond \& Savin-Williams, 2003; Kitzinger, 1987; Kitzinger \& Wilkinson, 1995; Richardson, 1984). (...) Individuals may experience variability in sexual orientation throughout their lives, Sexual orientation is perceived as constantly evolving from individual sexual and emotional experiences and the influence of the cultural context."

A specific challenge for the supporters of the thesis about the inherent nature and invariability of sexual orientation is bisexual identity. As described by Bancroft (2019, p. 272273), the gay movement rejected bisexuality as an identity, considering it a justification for men who had difficulty accepting their own homosexual identity and constituting a threat to the political benefits resulting from the thesis of innate and unchanging homosexual orientation. Research by Weinberg (1994, after Bancroft, 2019) shows that in the examined bisexual group heterosexuality was first established, and the homosexual component appeared later. Establishing a bisexual identity usually came late (at the age of twenty or later) compared to groups identifying as purely heterosexual or homosexual, there were also differences in the experience of bisexuality between women and men.

One phenomenon that should be taken into account when discussing the emerging homosexual orientation in adolescents is the relationship between sexual harassment and the later belief in one's own sexual otherness. Imieliński (1963) cites research on inmates of correctional facilities and boarding schools: as many as $78 \%$ of people with homosexual inclinations from these environments experienced homosexual seduction (or even rape). The author states that those seduced between the ages of 6 and 14 were characterised by heterosexual indifference or disgust, while seduction over the age of 14 resulted in the development of bisexuality. More recent research also shows similar dependencies. Purely homosexual women experienced sexual harassment in childhood more than twice as often as purely heterosexual women (17\% vs. $39 \%)$. It was also associated with a higher risk of sexual abuse in adulthood (Hughes i in., 2010). There are a number of research reports showing a disproportionately high proportion of adult homosexuals or bisexuals (compared to the heterosexual population) who have experienced childhood sexual abuse (Brennan et al., 2007; Rothman et al., 2011; Tomeo et al., 2001). The declaration of non-heterosexuality, commonly known as coming out, in these cases may not be so much a manifestation of sexual integration as a call for help.

The research conducted so far on the effects of coming-out on adolescents indicates that such a decision has negative consequences for mental and physical health as well as social relations. Norwegian studies show that early coming out in the case of adolescents 
(under 15 years of age) increases the risk of suicide attempts (Hegna \& Wichstrøm, 2007). Research by Remafedi et al. (1998) shows that in the case of adolescents feeling sexually attracted to their own sex, two factors turned out to be protective against committing suicide attempts: delaying coming out and not engaging in sexual behaviour. Adolescents declaring themselves as non-heterosexual engage in sexual intercourse earlier than their peers (Garofalo et al., 1998). Boys who engage in sexual contact with men are particularly vulnerable to STDs and HIV (Lemp i in., 1994). Even education about condom use does not help prevent infection (Altman, 2008). Furthermore, men who have sex with men are 19 times more likely to become infected with HIV than the rest of the population. As many as $4 \%$ of this population becomes infected with HIV before the age of 25 . For comparison, in the general population of people under the age of 25, only a fraction of a percent is infected with HIV (GAP Report, 2014). Recent data shows that 57\% of new AIDS infections in Western Europe, Central Europe and North America are men who have sex with men (UNAIDS, 2018). Adolescents who define themselves as non-heterosexual are also more likely to become addicted to drugs and alcohol than their heterosexual peers (Garofalo et al., 1998; Halkitis et al., 2005; McCabe et al., 2005).

\section{Summary}

Differences in attitudes towards homosexual orientation result from different answers given to the basic question about its causes. If it is assumed that homosexual orientation is essentially inborn and constant, then the model of affirmative therapy is justified and supports the manifestations of homosexual behaviour in adolescents, treated as signals of a true homosexual nature emerging. Such a narrative is dominant in many authors who do not hide their affirmative approach to homosexuality and bisexuality. The consequence of such an approach will be the reversal of the traditional cause-and-effect order, e.g., disturbances in the parents-teenagers relationship will be described in terms of an inadequate reaction of parents to the homosexual signals sent by the child (Iniewicz, 2012). Nevertheless, we believe that the arguments provided by behavioural genetics and developmental psychology support the opposite view of treating sexual orientation as less genetically determined and variable in the course of life. There do not seem to be any serious reasons to treat psychosexual development as a process less complicated than personality development, as a process dependent on one or several genes. A natural consequence of this approach is a place for reorientation therapy in adults and not supporting homosexual behaviour in adolescents.

Teachers, tutors, educators, psychologists, and finally parents may come across a situation in which a teenager declares his homosexual orientation. There can be many reasons for this. Perhaps a teenager confuses their fascination and friendship with 
homosexual inclinations, perhaps some signals coming from the body (for example, night ejaculation, the occurrence of which coincided with the overnight stay at a friend's) make them feel so. Perhaps there are fantasies or dreams with erotic content involving people of his own sex, perhaps someone is trying to convince him that he is gay or a lesbian. Perhaps having an orgasm during same-sex sexual harassment prompts him to conclude that this is evidence of his homosexuality. Perhaps, as stated by Savin-Williams (2006), making declarations about one's sexuality is a call for help in freeing oneself from threatening conditions.

As the review of scientific findings shows, such claims from adolescents are unlikely to be supported. Broadly understood development, including the development of sexual orientation, lasts for years, it may turn out that after some time such feelings have disappeared, the teenager himself will decide that homosexual feelings were only temporary. If these feelings persist, it will be easier for him to deal with them without being labelled gay or lesbian. Perhaps such experiences resulted from completely different problems, e.g., because of sexual harassment and its misinterpretation as evidence of one's homosexuality. As sexual orientation in adolescence is in the process of being formed, young people may experience dreams, fantasies and even engage in homosexual behaviour - but, in most cases, such behaviour should not be interpreted as manifesting an established homosexual orientation. According to Paszewski (2016), there are many indications that each homosexual person has an individual history of forming his or her orientation, which, after all, can change. Hence, presenting to adolescents that sexual orientation is innate and unchanging appears to be unsubstantiated by scientific evidence. As shown in the cited research, most of the time there is a natural evolution towards heterosexuality. The question is whether the message based on the affirmation of homosexuality is not a form of violence against adolescents?

As already mentioned, adolescents who identify as non-heterosexual significantly more often than the rest become victims of sexual violence (forced sexual intercourse), 1 in 6 people declaring themselves as "non-heterosexual" in comparison with 1 in 19 heterosexual adolescents become victims of sexual violence during adolescence (Kann et al., 2016). Abused children and adolescents will primarily need assistance with sexual abuse trauma. Research showing a relationship between early sexual activity and health complications leads to the conclusion that early coming out and adopting a gay/lesbian identity is not a good solution also in this aspect.

In a famous text, Littman (Littman, 2018, 2019) points to a sudden increase in the number of cases of rapid-onset gender dysphoria as a result of the influence of the Internet and social media, and the functioning of youth in specific "information bubbles". A natural question arises to what extent these phenomena also affect youth adopting a homosexual 
orientation. These mechanisms seem to be noticed by Brodziak and Kłopotowski (2013, p. 265):

"It seems that too little attention has been paid to thorough prospective studies on adolescents with yet unknown sexual orientation, in whom it often changes. These people are nowadays influenced by previously rare cultural and educational patterns. Instead of parents' influences - now friends: peers, and especially older colleagues in school and the environment, and permissive contemporary (often niche) cultural patterns disseminated by the mass media have an overwhelming influence".

Obuchowska and Jaczewski (2002, p. 15), based on their extensive clinical and therapeutic experience, state:

"We are very against making a diagnosis of homosexuality in young people under 17 and 18 years of age. A young person, even with a large baggage of homosexual experiences, may - in a way that is unclear to us - overnight resign from their current homosexual orientation and assume a heterosexual role (it happens)".

In the context of the previously presented regularities regarding changes in the area of shaping sexual orientation, it is impossible to disagree with this approach. It should be noted, however, that some mental health researchers recommend that adolescents come out, treating it as a symptom of integrating sexuality and creating a mature identity, usually, such positions result not so much from a review of scientific research, but theoretical premises based on various therapeutic concepts, most often psychodynamic approaches. In this context, the previously mentioned Savin-Williams, a respected psychologist specialising in research on the non-heterosexual population, is known in Poland from the book Mom, Dad. I'm Gay, 2001; Polish edition (2011) emphasizes in a work written a few years later:

"Despite speculation by some clinicians, the claim that it is a good solution for a teenager to identify with their sexuality has not been proven. Clinicians like to assume that failure to adopt gay etiquette may be a symptom of psychological problems. The individual's resistance to accepting a sexual identity, they maintain, suggests a state of denial, denial, fear of confronting one's own sexual reality. But how can this view be reconciled with the overwhelming evidence - provided by the same clinicians - for alarmingly high levels of depression, drug use, risky sexual behaviour, and suicidal tendencies among adolescents who adopt the gay/lesbian label? Is it possible that young homosexuals adopting the label are more unhealthy than those who are sexually attracted to their own sex and who do not accept the label?" (Savin-Williams, 2006, p. 204).

The author refers to research by Sandfort (1997), which showed just such dependencies between coming out in adolescents and problems in the field of mental health and risky behaviour. Savin-Williams adds:

"It is true that in some cases, making declarations about one's sexuality is a cry for help in freeing oneself from threatening conditions, and other people are healthy because 
they have different bases for self-determination than sexuality. More developmentally adequate foundations" (Savin-Williams, 2006, p. 204).

The author draws attention to the increasingly popular rejection of labels concerning their sexuality by teenagers. For some, the label "gay" or "lesbian" is a label associated with political activism with which they do not want to be identified. Others see this label as reducing their identity to sexuality and therefore refuse to come out. Still others consider their sexuality to be much less important to their identity than other aspects of their person (e.g., personality traits, passions, social roles). The researcher believes that this is a positive phenomenon.

The introduction deals with the topic of natural differences between various scientific disciplines in looking at the phenomenon of sexual orientation. It is also worth discussing the issue of the therapeutic relationship. The Code of Professional Ethics of the Psychologist of the PPA emphasises the need to respect the dignity of the human person, his subjectivity and autonomy as well as the right to unhampered development. In therapeutic practice it is carried out with the help of the so-called therapeutic contracts, i.e., possible areas of work that are accepted by both the client and the therapist. Based on our knowledge of the community, we are convinced that if a client with a homosexual orientation but with problems of a different nature (e.g. in the area of interpersonal conflicts) approached the therapist, the vast majority of psychotherapists (including the authors of this piece of work) would work only in this area, without any pressure to the necessity to change sexual orientation. However, the specificity of the psychologist-adult client relationship cannot be automatically transferred to the psychologist-teenage client relationship, and, in our opinion, it cannot be cut off from the educational and advisory dimensions. The achievements of developmental psychology show that adolescence is characterised by high dynamics of changes, it is the proverbial time of a "hormonal storm" causing large fluctuations in mood, emotionality or objects of identification, usually without full formal thinking abilities. It would be a kind of paradox to leave adolescents to themselves with regard to their dilemmas regarding the shaping of sexual orientation, in a situation where in other areas of life the society imposes certain restrictions on them resulting from the lack of formal maturity and full civil rights. In this context, the suggestion addressed to teenagers to refrain from coming out seems perfectly justified. It is also supported by a number of cited research reports pointing to the variability of sexual orientation, led by the longitudinal studies by SavinWilliams and Ream (2007) and Ott et al. (2011) carried out in impressive numbers.

In the case of a psychologist as a counsellor/therapist relationship, the clientteenager's welfare is understood in the first place as their right to broad, exhaustive information about developmental regularities and mechanisms of shaping sexual orientation. 


\section{Bibliography:}

Alexander, G.M., Wilcox, T., \& Woods, R. (2009). Sex Differences in Infants' Visual Interest in Toys, Archives of Sexual Behavior, 38 (3), 427-433, https:/ / doi.org/10.1007/s10508-0089430-1.

Altman, L. (2008, sierpień 3). H.I.V. Study Finds Rate 40\% Higher Than Estimated, The New York Times, https://www.nytimes.com/2008/08/03/health/03aids.html (access: 05.02.2011).

American Psychological Association. (2008). Answers to your questions: For a better understanding of sexual orientation and homosexuality, www.apa.org/topics/sorientation.pdf (access: 14.06.2012).

American Psychological Association (2009). Report of the Task Force on Appropriate Therapeutic Responses to Sexual Orientation, American Psychological Association, https://www.apa.org/pi/lgbt/resources/therapeutic-response.pdf (access: 08.10.2010).

American Psychological Association (2018). Answers to your questions: For a better understanding of sexual orientation and homosexuality, https://www.apa.org/topics/lgbt/orientation (access: 05.05.2019).

Bailey, J.M., Miller, J.S., \& Willerman, L. (1993). Maternally rated childhood gender nonconformity in homosexuals and heterosexuals, Archives of Sexual Behavior, 22 (5), 461-469, https:/ / doi.org/10.1007/BF01542559.

Bancroft, J. (2019). Seksualność człowieka, Wrocław: Edra Urban \& Partner.

Bearman, P. S., \& Brückner, H. (2002). Opposite- Sex Twins and Adolescent Same- Sex Attraction, American Journal of Sociology, 107 (5), 1179-1205, https://doi.org/ $10.1086 / 341906$.

Beisert, M. (Ed.). (2012). Seksualność w cyklu życia człowieka, Warszawa: Wydawnictwo Naukowe PWN.

Bockting, W.O. (2014). Transgender identity development, (in:) D.L. Tolman \& L.M. Diamond (Eds.), APA handbook of sexuality and psychology, Vol. 1: Person-based approaches, p. 739-758. Washington: American Psychological Association, https://doi.org/10.1037/14193-024.

Bogaert, A. F., \& Hershberger, S. (1999). The Relation Between Sexual Orientation and Penile Size, Archives of Sexual Behavior, 28 (3), 213-221, https://doi.org/10.1023/ A:1018780108597.

Brennan, D.J., Hellerstedt, W.L., Ross, M.W., \& Welles, S.L. (2007). History of Childhood Sexual Abuse and HIV Risk Behaviors in Homosexual and Bisexual Men, American Journal of Public Health, 97 (6), 1107-1112, https:/ / doi.org/10.2105/ AJPH.2005.071423.

Brodziak, A., \& Kłopotowski, T. (2013). Biologiczne i środowiskowe uwarunkowania orientacji seksualnej, Annales Academiae Medicae Silesiensis, 67 (4), 256-267. 
Bryant, P., \& Colman, A. (1995). Psychologia rozwojowa, Poznań: Wydawnictwo Zysk i S-ka.

Czyżowska, D. (2005). Style tożsamości a rozwój rozumowania moralnego jednostki, Psychologia Rozwojowa, 10 (4), 3-82.

Dahl, R.E. (2004). Adolescent Brain Development: A Period of Vulnerabilities and Opportunities. Keynote Address, Annals of the New York Academy of Sciences, 1021 (1), 1-22, https:// doi.org/10.1196/annals.1308.001.

Diamond, L.M. (2000). Sexual identity, attractions, and behavior among young sexualminority women over a 2-year period, Developmental Psychology, 36 (2), 241-250, https://doi.org/10.1037/0012-1649.36.2.241.

Diamond, L.M. (2014). Gender and same-sex sexuality, In: D.L. Tolman \& L.M. Diamond (Eds.), APA Handbook of Sexuality and Psychology, Volume 1. Person Based Approaches, I, T. 1, 629-652, Washington, DC: American Psychological Association.

Diamond, L.M., \& Rosky, C.J. (2016). Scrutinizing Immutability: Research on Sexual Orientation and U.S. Legal Advocacy for Sexual Minorities, The Journal of Sex Research, 53 (4-5), 363-391, https:/ / doi.org/10.1080/00224499.2016.1139665.

Dickson, N., van Roode, T., Cameron, C., \& Paul, C. (2013). Stability and Change in Same-Sex Attraction, Experience, and Identity by Sex and Age in a New Zealand Birth Cohort, Archives of Sexual Behavior, 42(5), 753-763, https:/ / doi.org/10.1007/s10508-012-0063-z.

Eliot, L. (2011). Różowy mózg, niebieski mózg: Jak niewielkie różnice w mózgach dziewczynek i chłopców moga stać się przepastne i co z tym zrobić, Poznań: Media Rodzina.

Erikson, E.H. (2004). Tożsamość a cykl życia, Poznań: Zysk i S-ka.

Ganna, A., Verweij, K.J.H., Nivard, M.G., Maier, R., Wedow, R., Busch, A.S., Zietsch, B.P. (2019). Large-scale GWAS reveals insights into the genetic architecture of same-sex sexual behavior, Science, 365 (6456), https:/ / doi.org/10.1126/science.aat7693.

GAP Report. (2014). Gay men and other men who have sex with men. Joint United Nations Programme on HIV/AIDS (UNAIDS), UNAIDS, https://www.unaids.org/en/resources/documents/2014/Gaymenandothermenwh ohavesexwithmen (access: 07.11.2019).

Garnets, L.D. (2002). Sexual orientations in perspective, Cultural Diversity and Ethnic Minority Psychology, 8 (2), 115-129, https:/ / doi.org/10.1037/1099-9809.8.2.115.

Garofalo, R., Wolf, R.C., Kessel, S., Palfrey, J., \& DuRant, R.H. (1998). The Association Between Health Risk Behaviors and Sexual Orientation Among a School-based Sample of Adolescents, PEDIATRICS, 101 (5), 895-902, https://doi.org/10.1542/ peds.101.5.895.

Grunt-Mejer, K., \& Iniewicz, G. (2020). Psychospołeczne korelaty orientacji seksualnej, in: W.Ł. Dragan \& G. Iniewicz (Eds.), Orientacja seksualna. Źródła i konteksty, 15-49, Warszawa: Wydawnictwo Naukowe SCHOLAR. 
Halkitis, P.N., Wilton, L., \& Drescher, J. (red.). (2005). Barebacking: Psychosocial and public health approaches, New York: Haworth Medical Press.

Hall, J.A., \& Kimura, D. (1995). Sexual orientation and performance on sexually dimorphic motor tasks, Archives of Sexual Behavior, 24 (4), 395-407, https://doi.org/10.1007/bf01541855.

Hamer, D.H., \& Copeland, P. (2007). Geny a charakter: Jak sobie radzić z genetycznym dziedzictwem, Warszawa: Wydawnictwo CiS.

Hamer, D., Hu, S., Magnuson, V., Hu, N., \& Pattatucci, A. (1993). A linkage between DNA markers on the $X$ chromosome and male sexual orientation, Science, 261 (5119), 321327, https:/ / doi.org/10.1126/ science.8332896.

Hegna, K., \& Wichstrøm, L. (2007). Suicide Attempts among Norwegian Gay, Lesbian and Bisexual Youths: General and Specific Risk Factors, Acta Sociologica, 50 (1), 21-37, https://doi.org/10.1177/0001699307074880.

Hughes, T.L., Szalacha, L.A., Johnson, T.P., Kinnison, K.E., Wilsnack, S.C., \& Cho, Y. (2010).

Sexual victimization and hazardous drinking among heterosexual and sexual minority women, Addictive Behaviors, 35 (12), 1152-1156,

https://doi.org/10.1016/j.addbeh.2010.07.004.

Imieliński, K. (1963). Geneza homo- $i$ biseksualizmu środowiskowego: Teoria orientacji płciowej, Warszawa: Państwowy Zakład Wydawnictw Lekarskich.

Iniewicz, G. (2012). Osoby LGB w biegu życia, (in:) G. Iniewicz, M. Mijas, \& B. Grabski (eds.), Wprowadzenie do psychologii LGB, 139-153, Wrocław: Wydawnictwo Continuo.

Iniewicz, G., Mijas, M., \& Grabski, B. (Eds.). (2012). Wprowadzenie do psychologii LGB, Wrocław: Wydawnictwo Continuo.

Izdebski, Z. (2006). Ryzykowna dekada: Seksualność Polaków w dobie HIV/AIDS: studium porównawcze 1997-2001-2005, Zielona Góra: Oficyna Wydawnicza Uniwersytetu Zielonogórskiego.

Izdebski, Z. (2012). Seksualność Polaków na poczatku XXI wieku: Studium badawcze (Wyd. 1), Kraków: Wydawnictwo Uniwersytetu Jagiellońskiego.

Kann, L., McManus, T., Harris, W.A., Shanklin, S.L., Flint, K.H., Hawkins, J., Zaza, S. (2016). Youth Risk Behavior Surveillance-United States 2015, MMWR, Surveillance Summaries, 65 (6), 1-174, https://doi.org/10.15585/mmwr.ss6506a1.

Kernberg, O.F. (1998). Związki miłosne: Norma i patologia, Poznań: Zysk i S-ka.

Kinnish, K.K., Strassberg, D.S., \& Turner, C.W. (2005). Sex Differences in the Flexibility of Sexual Orientation: A Multidimensional Retrospective Assessment, Archives of Sexual Behavior, 34 (2), 173-183, https://doi.org/10.1007/s10508-005-1795-9.

Kleinplatz, P.J., \& Diamond, L.M. (2014). Sexual diversity, (in:) D.L. Tolman \& L.M. Diamond (eds.), APA handbook of sexuality and psychology, Vol. 1: Person-based approaches, 245- 
267, Washington: American Psychological Association, https://doi.org/10.1037/14193-009.

Kohlberg, L. (1984). The psychology of moral development: The nature and validity of moral stages (1st ed.), San Francisco: Harper \& Row.

Kosslyn, S.M., \& Rosenberg, R.S. (2006). Psychologia: Mózg, człowiek, świat, Kraków: Wydawnictwo Znak.

Lalumière, M.L., Blanchard, R., \& Zucker, K.J. (2000). Sexual orientation and handedness in men and women: A meta-analysis, Psychological Bulletin, 126 (4), 575-592, https://doi.org/10.1037/0033-2909.126.4.575.

Larson, R., \& Richards, M. (1994). Family Emotions: Do Young Adolescents and Their Parents Experience the Same States? Journal of Research on Adolescence, 4 (4), 567-583.

Lemp, G.F., Hirozawa, A.M., Givertz, D., Nieri, G.N., Anderson, L., Lindegren, M.L., ... Katz, M. (1994). Seroprevalence of HIV and risk behaviors among young homosexual and bisexual men. The San Francisco/Berkeley Young Men's Survey, JAMA, 272 (6), 449454.

LeVay, S. (1991). A difference in hypothalamic structure between heterosexual and homosexual men, Science, 253 (5023), 1034-1037, https://doi.org/10.1126/science.1887219.

Littman, L. (2018). Parent reports of adolescents and young adults perceived to show signs of a rapid onset of gender dysphoria, PLOS ONE, 13 (8), 1-44, https:/ / doi.org/10.1371/ journal.pone.0202330.

Littman, L. (2019). Correction: Parent reports of adolescents and young adults perceived to show signs of a rapid onset of gender dysphoria, PLOS ONE, 14 (3), https:/ / doi.org/ 10.1371/journal.pone.0214157.

Manning, J.T., Scutt, D., Wilson, J., \& Lewis-Jones, D.I. (1998). The ratio of 2nd to 4th digit length: A predictor of sperm numbers and concentrations of testosterone, luteinizing hormone and oestrogen, Human Reproduction, 13 (11), 3000-3004, https://doi.org/ 10.1093/humrep/13.11.3000.

Marcia, J.E. (1966). Development and validation of ego-identity status, Journal of Personality and Social Psychology, 3 (5), 551-558, https:// doi.org/10.1037/h0023281.

Mayer, L.S., \& McHugh, P.R. (2016). Sexuality and Gender. Findings from the Biological, Psychological, and Social Sciences, The New Atlantis. Special Report, 50, 1-144.

McCabe, S.E., Hughes, T.L., Bostwick, W., \& Boyd, C.J. (2005). Assessment of difference in dimensions of sexual orientation: Implications for substance use research in a collegeage population, Journal of Studies on Alcohol, 66 (5), 620-629,

https://doi.org/10.15288/jsa.2005.66.620. 
Millon, T., Davis, R.D., Millon, C., Escovar, L., \& Meagher, S.E. (2013). Zaburzenia osobowości we wspótczesnym świecie, Warszawa: Instytut Psychologii Zdrowia. Polskie Towarzystwo Psychologiczne.

Miluska, J. (1996). Kulturowy kontekst procesu formowania tożsamości, Forum Psychologiczne, I (1-2), 83-96.

Modrzejewska, R., \& Bomba, J. (2009). Porównanie objawów depresji w populacji uczniów krakowskich szkół podstawowych w latach 1984 i 2001, Psychiatria Polska, XLIII(2), 167-174.

Musiał, D. (2007). Kształtowanie się tożsamości w adolescencji, Studia z Psychologii KUL, 14, 73-92.

Obuchowska, I., \& Jaczewski, A. (2002). Rozwój erotyczny, Warszawa: Żak.

Oleszkowicz, A., \& Senejko, A. (2016). Dorastanie, In: J. Trempała (Ed.), Psychologia rozwoju człowieka I, 259-287, Warszawa: Wydawnictwo Naukowe PWN SA.

Oniszczenko, W., \& Dragan, W.Ł. (2008). Genetyka zachowania w psychologii i psychiatrii, Warszawa: Wydawnictwo Naukowe SCHOLAR.

Ott, M.Q., Corliss, H.L., Wypij, D., Rosario, M., \& Austin, S.B. (2011). Stability and Change in Self-Reported Sexual Orientation Identity in Young People: Application of Mobility Metrics, Archives of Sexual Behavior, 40(3), 519-532, https://doi.org/ 10.1007/s10508010-9691-3.

Paszewski, A. (2016). Przyczyny orientacji homoseksualnej-Co wnoszą do wiedzy badania nad bliźniakami, Family Forum, 6, 31-43.

Peplau, L.A., \& Garnets, L.D. (2000). A New Paradigm for Understanding Women's Sexuality and Sexual Orientation, Journal of Social Issues, 56 (2), 330-350, https://doi.org/10.1111/0022-4537.00169.

Pervin, L.A., \& John, O.P. (2002). Osobowość: Teoria i badania, Kraków: Wydawnictwo Uniwersytetu Jagiellońskiego.

Piaget, J. (2012). Mowa i myślenie dziecka, Warszawa: Wydawnictwo Naukowe PWN.

Pinker, S. (2012). Tabula rasa: Spory o naturę ludzką, Gdańsk: Gdańskie Wydawnictwo Psychologiczne.

Plomin, R., DeFries, J., McClearn, G., \& McGuffin, P. (2001). Genetyka zachowania, Warszawa: Wydaw. Naukowe PWN.

Rahman, Q., \& Silber, K. (2000). Sexual Orientation and the Sleep-Wake Cycle: A Preliminary Investigation, Archives of Sexual Behavior, 29 (2), 127-134, https:// doi.org/ 10.1023/A:1001999821083.

Remafedi, G., French, S., Story, M., Resnick, M.D., \& Blum, R. (1998). The relationship between suicide risk and sexual orientation: Results of a population-based study, American Journal of Public Health, 88 (1), 57-60, https:/ / doi.org/10.2105/ AJPH.88.1.57. 
Rosario, M., \& Schrimshaw, E.W. (2014). Theories and etiologies of sexual orientation, (in:) D.L. Tolman \& L.M. Diamond (Eds.), APA Handbook of Sexuality and Psychology, Volume 1. Person Based Approaches, T. 1, 555-596, Washington, DC: American Psychological Association.

Rosenblum, G., \& Lewis, M. (2004). Emotional development in adolescence, (in:) G. Adams \& M. Berzonsky (eds.), Blackwell Handbook of Adolescence, 270-285, Malden, MA: Blackwell Publishing.

Rothman, E.F., Exner, D., \& Baughman, A.L. (2011). The Prevalence of Sexual Assault Against People Who Identify as Gay, Lesbian, or Bisexual in the United States: A Systematic Review, Trauma, Violence, \& Abuse, 12 (2), 55-66, https://doi.org/ 10.1177/1524838010390707.

Sandfort, T. (1997). Sampling male homosexuality, In: J. Bancroft (Ed.), Researching sexual behavior: Methodological issues,261-275, Bloomington: Indiana University Press.

Savin-Williams, R.C. (2006). The new gay teenager, Cambridge, Mass.: Harvard University Press, https://ebookcentral.proquest.com/lib/qut/detail.action?docID=3300069 (access: 02.09.2018).

Savin-Williams, R.C. (2011). Homoseksualność w rodzinie: Ujawnianie tajemnicy, Sopot: Gdańskie Wydawnictwo Psychologiczne.

Savin-Williams, R.C., \& Ream, G.L. (2007). Prevalence and Stability of Sexual Orientation Components During Adolescence and Young Adulthood, Archives of Sexual Behavior, 36 (3), 385-394, https:/ / doi.org/10.1007/s10508-006-9088-5.

Seligman, M.E.P., Walker, E.F., \& Rosenhan, D.L. (2017). Psychopatologia, Poznań: Zysk i S-ka. Silventoinen, K., Magnusson, P.K.E., Tynelius, P., Kaprio, J., \& Rasmussen, F. (2008). Heritability of body size and muscle strength in young adulthood: A study of one million Swedish men, Genetic Epidemiology, 32 (4), 341-349, https://doi.org/10.1002/gepi.20308.

Strauch, B. (2004). The primal teen: What the new discoveries about the teenage brain tell us about our kids, New York: Anchor Books, https://archive.org/details/primalteen00barb (access: 05.06.2018).

Tomeo, M.E., Templer, D.I., Anderson, S., \& Kotler, D. (2001). Comparative Data of Childhood and Adolescence Molestation in Heterosexual and Homosexual Persons, Archives of Sexual Behavior, 30 (5), 535-541, https:/ / doi.org/10.1023/ A:1010243318426.

UNAIDS. (2018). UNAIDS Data 2018,

https://www.unaids.org/sites/default/files/media_asset/unaids-data-2018_en.pdf (access: 12.10.2019).

Whitehead, N., \& Whitehead, B. (2018). My genes made me do it!: Homosexuality and the scientific evidence, Lower Hutt: Whitehead Associates, http://natlib- 
primo.hosted.exlibrisgroup.com/NLNZ:NLNZ:NLNZ_ALMA11308397860002836 (access: 12.10.2019).

Whitehead, N.E. (2011). Neither Genes nor Choice: Same-Sex Attraction Is Mostly a Unique Reaction to Environmental Factors, Journal of Human Sexuality, (3), 81-114, https://www.researchgate.net/publication/285329852_Neither_genes_nor_choice_S ame-sex_attraction_is_mostly_a_unique_reaction_to_environmental_factors (access: 12.02.2013).

Wolański, N. (2012). Rozwój biologiczny człowieka: Podstawy auksologii, gerontologii i promocji zdrowia, Warszawa: Wydawnictwo Naukowe PWN. 